\title{
AS FORMAS DA HISTÓRIA. A DOUTRINA AGOSTINIANA DAS SEIS IDADES DO MUNDO E ALGUMAS DE SUAS VISUALIZAÇÕES NO SÉCULO XII*
}

\author{
Elisa Brilli \\ Kunsthistorisches Institut in Florenz \\ Max-Planck-Institut
}

\begin{abstract}
Resumo
Este artigo estuda a doutrina das seis idades do mundo, concebida por Santo Agostinho e amplamente difundida no Ocidente medieval. Após analisar a teorização de Agostinho, com base em fontes diversas, passa-se ao exame das iluminuras de três manuscritos que buscaram dar forma visual a essa concepção da história no século XII.
\end{abstract}

\section{Palavras-chave}

Agostinho $\bullet$ história $\bullet$ imagem.

\section{Contato:}

Kunsthistorisches Institut in Florenz, Max-Planck-Institut

Via Giuseppe Giusti 44

50121 - Firenze - Italia

E-mail: e.brilli@gmail.com

* Tradução de Eduardo Henrik Aubert. Todas as imagens mencionadas neste artigo estão reproduzidas no Caderno de imagens. 


\title{
THE FORMS OF HISTORY. AUGUSTINE'S THEORY OF THE SIX AGES OF THE WORLD AND SOME OF ITS VISUAL REPRESENTATIONS IN THE TWELFTH CENTURY*
}

Elisa Brilli

Kunsthistorisches Institut in Florenz

Max-Planck-Institut

\begin{abstract}
This article studies the theory of the six ages of the world, formulated by Augustine and widespread in the medieval West. After analysing Augustine's formulations, on the basis of his multiple sources, the text examines the three illuminated manuscripts, all dated to the twelfth century, that sought to give visual form to this conception of history.
\end{abstract}

Keywords

Augustine $\bullet$ history $\bullet$ image.

\section{Contact:}

Kunsthistorisches Institut in Florenz, Max-Planck-Institut

Via Giuseppe Giusti 44

50121 - Firenze - Italia

E-mail: e.brilli@gmail.com

* Translation by Eduardo Henrik Aubert. 
A doutrina das seis idades do mundo, definida por Agostinho de Hipona, constitui, sem dúvida, uma das estruturas fundamentais da concepção de história no Ocidente cristão. As páginas que se seguem apresentam uma análise da elaboração agostiniana e de sua problemática originária. Em seguida, o texto passará à fortuna de tal construção na tradição medieval, para depois se concentrar em algumas de suas visualizações gráficas e iconográficas elaboradas no decurso do século XII, em particular no Liber Floridus, de Lambert de Saint-Omer, na Bíblia de Winchester e, mais detalhadamente, em um exemplar do De civitate Dei proveniente do mosteiro beneditino de Santa Maria de Bosau, na Saxônia.

\section{A doutrina agostiniana das seis idades do mundo: fontes e referentes polêmicos}

A doutrina segundo a qual a história da humanidade, desde a criação ao juízo universal, articula-se em seis idades é considerada corretamente uma invenção original de Agostinho de Hipona. ${ }^{1}$ Como no caso das principais elaborações agostinianas, esta também deriva da rede de múltiplas tradições anteriores, tanto patrísticas quanto pagãs, que Agostinho reinterpreta de modo a fazê-las convergir em um sistema unitário. Ao mesmo tempo, para compreender o sentido para além das fontes do pensamento agostiniano, é preciso levar em consideração seus referentes e, assim, sua função polêmica e apologética.

No que concerne aos seus antecedentes, a doutrina das seis idades do mundo envolve três textos e suas relativas tradições interpretativas. A primeira referência de Agostinho é a narrativa da Gênesis sobre os seis dias da criação, interpretada à luz do versículo 4 do salmo 89, segundo o qual mille anni ante oculos tuos tamquam dies hesterna quae praeteriit. Esse dispositivo interpretativo e, portanto, a associação intratestamentária entre o trecho da Gênesis e o salmo 89 já estavam estabelecidos na tradição exegética hebraica, na qual ela havia dado origem à elaboração da doutrina dos seis mil anos da história. Em termos breves, da mesma forma que Deus cumprira a criação em seis dias, a história do mundo se cumprirá em seis mil anos. A esse substrato, a cultura judaico-cristã havia desde então acrescentado a referência ao debatido capítulo XX do Apocalipse de João, definindo a doutrina chamada milenarista ou quilialista. De acordo com os partidários dessa doutrina, aos seis mil anos da história prefigurados pelos seis

\footnotetext{
Sobre a doutrina das seis idades da história, cf. SCHMIDT, Roderich. Aetates mundi. Die Weltalter als Gliederungsprinzip der Geschichte. Zeitschrift für Kirchengeschichte, 67, 1955-1956, p. 208317; LUNEAU, Auguste. L'histoire du salut chez les pères de l'Église, la doctrine des âges du monde. Paris: Beauchesne, 1964; SCHWARTE, Karl-Heinz. Die Vorgeschichte der augustinischen Weltalterlehre. Bonn: R. Habelt, 1966 («Antiquitas. I. Abhandlungen zur alten Geschichte», 12).
} 
dias da criação (isto é, da queda de Adão até o primeiro encarceramento de Satanás), ter-se-ia seguido uma primeira ressurreição dos justos; eles teriam gozado do reino de Cristo sobre a Terra por mil anos, a sétima idade correspondente ao sabbat da Gênesis; o último milênio ter-se-ia concluído com um novo encontro com Satanás, sua derrota definitiva, a segunda ressurreição, o juízo universal e a recompensa eterna dos eleitos e dos danados. Se Agostinho sofrera o fascínio do milenarismo, ${ }^{2}$ ele posteriormente se afastou dele, refutando tanto a crença em uma dupla ressurreição (aquela apenas dos justos ao fim da sexta idade e a universal ao fim da sétima idade) quanto a crença em um reino excessivamente material do Cristo sobre a Terra. Sem percorrer novamente cada ponto da refutação, cuja conclusão se lê no capítulo 7 do livro XX do De civitate, ${ }^{3}$ bastará manter presente que a doutrina das seis idades da história é concebida expressamente com uma função antiquilialista.

A segunda referência agostiniana é a parábola evangélica dos vinhateiros ( $M t$ 20, 1-16). Conta Jesus: na terceira hora, um patrão sai para buscar operários para trabalharem em sua vinha (que é um símile, segundo o texto do Evangelho, do reino dos céus) e acorda com eles o pagamento de um denário; o mesmo contrato se passa com outros operários na sexta, na nona e na undécima horas. Ao fim da jornada de trabalho, o patrão dá o mesmo salário a todos, independentemente das horas efetivamente trabalhadas, e isso a começar pelos últimos dos vinhateiros. A quem se lamenta, o patrão responde que aquele fora o preço acordado e a parábola se conclui com a passagem celebérrima: sic erunt novissimi primi et primi novissimi multi sunt enim vocati pauci autem electi (v. 16). Ao passo que a primeira exegese desse texto é principalmente de tipo tropológico ou cristológico, Orígenes, em primeiro lugar, propõe associar as cinco horas da parábola evangélica a cinco grupos de personagens bíblicos, encabeçados respectivamente por Adão, Noé, Abraão, Moisés e Cristo, propondo, assim, uma alegorese cristã de sentido histórico-universal. ${ }^{4}$

A terceira referência da elaboração agostiniana provém, diversamente, da tradição clássica. Trata-se do esquema das seis idades da vida individual, tal qual Agostinho podia ler, em especial, no De republica ciceroniano. Esse esquema já havia sido posto em relação, na tradição grega e latina, com as parábolas de

2 Cf.AUGUSTINUS HIPPONENSIS. Sermo 259 e FOLLIET, George. La typologie du sabbat chez saint Augustin. Son interpretation millénariste entre 389 et 400 . Revue des études augustiniennes, 2, 1956, p. 371-90.

3 Cf. também AUGUSTINUS HIPPONENSIS. De haer. VIII e En. in ps. 6, 1.

4 Cf. TEVEL, J.-M. The labourers in the vineyard: The exegesis of Matthew 20. 1-7 in the Early Church. Vigiliae Christianae, 46/4, 1992, p. 356-80. 
desenvolvimento e degeneração dos governos políticos e, na primeira patrística, havia conhecido uma interessante reutilização com um sentido cristológico. ${ }^{5}$

A complexa rede dessas referências encontrou uma primeira sistematização no De genesi contra Manicheos, redigido entre 387 e 390 d.C. Nesta obra, Agostinho postulava a correspondência entre os dias da criação, as idades do indivíduo e as da história universal; ele indexava o patriarca e o episódio de abertura e fechamento de cada idade e, por fim, calculava o número de gerações correspondentes. A passagem de uma idade a outra correspondia a uma culpa da humanidade (a perversão anterior ao dilúvio, a construção da torre de Babel, o pecado de Saul, o pecado do rei de Israel e, por fim, o pecado de todo o povo hebreu, artífice do desconhecimento e da crucifixão) e à punição divina correspondente (respectivamente: o Dilúvio, a confusio linguarum, a deposição de Saul, o exílio na Babilônia, a diáspora de 70 d.C.). ${ }^{6}$ A série responde, portanto, a um módulo rítmico sempre idêntico a si mesmo, o da transgressão e punição destinada ao epílogo grandioso do Juízo Final, mas ela não é monótona. Não se trata tanto de uma variação de gravidade (cada pecado reproduz, com efeito, a praeuaricatio original, tratando-se, para Agostinho, de pecados de soberba), mas, antes, de uma amplidão da adesão ao pecado. A figura é a de um arco. O arco da história veterotestamentária, cujo ápice coincide com o reino de Davi; o arco da vida humana, que sobe da infância à idade adulta para cair pouco a pouco até a morte; o arco, por fim, pois a ideia clássica é bastante familiar a Agostinho, de todo governo terreno. O conjunto desses dados pode ser resumido no esquema representado na figura 1 , em que eu inseri também as referências à parábola evangélica de $M t$ 20, que Agostinho desenvolve no Sermo 87, 5-7.7

Como já foi dito mais acima, essa formalização se compreende melhor quando se têm presentes os referenciais polêmicos e apologéticos de Agostinho; neste caso, trata-se da tradição exegético-historiográfica hebraica, da doutrina cristã milenarista e da tradição pagã. A história sacra hebraica era articulada em fases, cada uma intitulada a um patriarca, ritmadas pela renovação do pacto de Deus com o povo eleito. Em aparência fiel a essa estruturação, a doutrina das seis

5 Cf. ARCHAMBAULT, Paul. The ages of man and the ages of the world. A study of two traditions. Revue des études augustiniennes, 12, 1966, p. 193-228 e BURROW, John A. The ages of man: a study in medieval writing and thought. Oxford: Clarendon Press, 1986.

6 AUGUSTINUS HIPPONENSIS. De gen. contra man. I 23-25. In: PL 34, col. 191-194.

7 A referência às horas da parábola causa um problema devido à ausência de correspondência entre os seis dias da criação e as cinco horas da parábola. Contudo, Agostinho não renuncia a utilizá-la e resolve a dificuldade evitando citar a segunda idade (razão pela qual o espaço correspondente no esquema está vazio). 
idades confere-lhe um sentido completamente diverso. A associação da história veterotestamentária com os seis dias da criação traçava, para Israel, uma trajetória globalmente ascendente; Agostinho, ao contrário, combinando essa associação e o esquema das idades da vida individual e orientando-os para a primeira e para a segunda parousia do Cristo, insiste na parábola de desenvolvimento e degeneração de Israel e trata a história veterotestamentária como uma epopeia extinta. Quando a história do povo eleito se esgota, quando o senex toca o ponto mais baixo de sua parábola vital - eis o paradoxo e o milagre dessa sexta idade - o homo novus aparece. A encarnação e a paixão de Cristo cumprem assim o percurso de Israel, abrindo, ao mesmo tempo, as portas para o renovamento universal (cujos termos conceituais são, neste ponto, exatamente correspondentes aos de Paulo: sucessão do homo nouus ao uetus, do spiritalis ao carnalis). Trata-se da tradução, em termos de teologia da história, da visão instrumental do reino de Israel, em prefiguração da revelação cristã, em termos exegéticos.

As implicações antimilenaristas do esquema das seis idades são ainda mais evidentes. Contrapondo-se à interpretação literal dos mil anos do salmo 89 e da Gênesis, Agostinho propõe um cômputo minucioso por gerações, ao qual corresponde uma duração desigual. $\mathrm{O}$ abandono da literalidade do número mil é tornado possível pela regra exegética dos números perfeitos (emprestada a Ticônio), segundo a qual eles significariam um longo período de tempo de duração indeterminada. Essa norma permite arquivar definitivamente a tese quilialista e assegurar a não previsibilidade da duração da sexta idade - e, assim, a não previsibilidade do juízo universal.

O terceiro e último interlocutor do esquema agostiniano das idades do mundo é a tradição clássica, tanto filosófica - e a referência aqui é à doutrina do eterno retorno - quanto historiográfica. Enquanto os pontos doutrinários concernentes à frente hebraica e quilialista estão assegurados há tempos e são simplesmente repetidos do De ciuitate Dei, a frente pagã é o referente principal no momento da redação da segunda parte do tratado. A doutrina das seis idades formaliza um dispositivo metonímico emboité, no qual todos os ritmos da criação correspondem-se perfeitamente (dias, horas, idades, fases da história universal). Entre as várias correspondências rítmicas, a mais grávida de consequências é aquela entre as seis idades da vida individual e as da história universal. O paralelismo, que subentende a interpretação do indivíduo como microcosmo, ${ }^{8}$ é perfeitamente cor-

8 Cf. AUGUSTINUS HIPPONENSIS. De ciu. Dei X 14: «Sicut autem unius hominis, ita humani generis, quod ad Dei populum pertinet, recta eruditio per quosdam articulos temporum tamquam aetatum profecit accessibus, ut a temporalibus ad aeterna capienda et a uisibilibus ad inuisibilia 
rente, mas se encontra aqui pela primeira vez historicizado em escala universal. O universo agostiniano, e depois medieval, nasce, cresce, envelhece e morre não muitas vezes, mas apenas uma, destinada à metamorfose final do último juízo, que o transformará em um universo perfeito; ${ }^{9}$ e, com ele, nasce, cresce, envelhece e morre a humanidade, destinada a ressurgir ao fim desse único ciclo para a glória ou para a condenação eterna. A correspondência ideada pela filosofia clássica entre a vida dos indivíduos e a parábola dos governos é estendida por Agostinho à história universal e essa extensão constitui a abertura do que podemos definir como o antropomorfismo histórico ainda característico do historicismo da filosofia da idade moderna. ${ }^{10}$ Menos evidentes, mas não menos fundamentais, são as implicações dessa doutrina no campo historiográfico. No momento da composição do De ciuitate Dei, a tradição cristã possuía apenas os modelos historiográficos da história eclesiástica e da crônica universal, representados respectivamente pela Historia ecclesiastica e pelo Chronicon de Eusébio de Cesareia. A história política permanecia, ao contrário, um apanágio da tradição pagã e o plano sinóptico da cronística universal eusebiana respeitava implicitamente essa hegemonia, retomando suas escansões. O De ciuitate põe abaixo essa ordem de coisas. A preeminência acordada à matéria veterotestamentária relativamente à matéria não cristã é de ordem não apenas quantitativa, mas estrutural, e isso dá um golpe na hegemonia historiográfica clássica, deitando as bases para a assimilação da matéria histórica pagã em perspectiva cristã. ${ }^{11}$ Agostinho abandona totalmente,

surgeretur»». O princípio já se encontra no De vera religione (redigido por volta de 390 d. C.) 27, 50: «sic proportione uniuersum genus humanum, cuius tamquam unius hominis uita est ab Adam usque ad finem huius saeculi, ita sub diuinae prouidentiae legibus administratur, ut in duo genera distributum appareat».

9 Cfr. De ciu. Dei XX 24, 1 em polêmica com Porfírio.

10 "Para os historiadores romanos, a história universal era a história de Roma, e as idades de Roma eram coextensivas às idades do mundo. Os pais da Igreja trouxeram dimensões muito mais amplas e supramundanas à história da humanidade; e quando quer que eles usem a imagem das idades do homem, eles as tornam análogas não às idades de uma sociedade ou império, mas às idades do mundo, às idades da história da salvação." (ARCHAMBAULT. The ages of man, cit., p. 200). Ver também o clássico LÖWITH, Karl. Meaning in history: the theological implications of the philosophy of history. Chicago: University of Chicago Press, 1949, que considera a crítica agostiniana das doutrinas clássicas do eterno retorno do mesmo a premissa cultural das filosofias historicistas modernas. Entre os estudos dedicados à influência agostiniana em alguns dos pais do historismo moderno, cf. HARDY, Georges. Le «De civitate Dei» source principale du «Discours sur l'Histoire universelle», Paris: E. Leroux, 1913 e VISMARA, Silvio. La storia in S. Agostino e in G. B. Vico. In: Sant'Agostino. Pubblicazione commemorativa del XV centenario della sua morte. Milão: Vita e Pensiero, 1931, p. 115-166.

${ }^{11}$ Cf. D'ELIA, Salvatore. Storia e teologia della storia nel «De ciuitate Dei». In: La storiografia ecclesiastica nella tarda antichità. Atti del convegno di Erice (1978). Messina: Centro di Studi Umanistici, 1980, p. 391-481: "Pela primeira vez, em uma síntese da história humana, e não 
em outros termos, os esquemas de matriz pagã e a doutrina dos quatro reinos ou impérios, o mais difundido desses esquemas, merece apenas uma breve citação do De ciuitate..$^{12}$ A razão parece residir na incongruência, do ponto de vista agostiniano, de um esquema inteiramente contingente como a sucessão dos impérios políticos, ao qual se prefere, assim, o esquema da história sacra. ${ }^{13}$ Uma vez fixado tal quadro, a história não cristã podia certamente ser incluída nele, mas justamente como conjunto de fatos privados de sentido intrínseco e, assim, sem capacidade de condicionar a estrutura e a periodização do todo.

Aquilo que, até agora, tenho chamado de história sacra e história pagã não é outra coisa, no léxico agostiniano, que a história respectivamente da ciuitas Dei e da ciuitas terrena (ou diaboli), das quais Agostinho fornece uma definição conceitual e terminológica no livro XIV do tratado. Os livros seguintes, até o XVIII, propõem-se a ilustrar o uniuersum tempus, siue seculum, da expulsão que se seguiu ao pecado original até o juízo universal, como articulação dos feitos, distintos e contrapostos entre si, dos cidadãos da cidade de Deus e daqueles de duas antagonistas. As duas ciuitates meta-históricas são assim tomadas por "regulae mysticae de interpretação da história da humanidade" 14 e esse esquema se combina com aquele, já esposto, das seis idades da história. Esse último, evocado pontualmente no decurso dos livros XIV a XVIII, é explicitado na última parte do tratado, em que a retomada das seis idades em que se articula o devir histórico se concentra na celebração da sétima, da requies sem fim que espera pelos beatos: "haec tamen septima erit sabbatum nostrum, cuius finis non erit uespera, sed

em um 'tratado teológico', a história do povo hebreu aparecia infinitamente mais importante do que a história grega e romana e do que aquela de outros povos, relegadas todas a um segundo plano, e postas sob o signo de Caim. Apenas o povo hebreu era o povo eleito, o povo da cidade de Deus" (p. 420).

${ }^{12}$ De origem helenística, essa doutrina circulou amplamente na tradição judaico-cristã por meio do sonho de Nabucodonosor e a visão das quatro bestas que saem do mar no livro de Daniel (respectivamente Dn 2 e 7-12), sem contar, no primeiro século da era cristã, o Apocalipse de João e, entre os apócrifos, o de Baruch e o Quarto livro de Esdras. No início do século V, ela fora defendida com autoridade por Jerônimo que, em seu comentário ao livro de Daniel, havia proposto a identificação dos quatro impérios com o babilônico, o medo-persa, o macedônio e, por fim, o romano. Agostinho cita essa doutrina, distanciando-se dela, em De ciu. Dei XX 23: «Quattuor illa regna exposuerunt quidam Assyriorum, Persarum, Macedonum et Romanorum. Quam uero conuenienter id fecerint, qui nosse desiderant, legant presbyteri Hieronymi librum in Danielem satis erudite diligenterque conscriptum» (com referência a Jerônimo, Comm. in Dan. 7, 1ss.).

${ }^{13}$ Cf. GUENEE, Bernard. Histoire et culture historique dans l'Occident médiéval. Paris: Aubier, 1980, p. 149: "a visão dos quatro reinos era decididamente demasiado ligada a realidades políticas excessivamente limitadas no tempo e no espaço. Ela pôde se integrar a uma ideologia política. Ela nunca pôde estruturar uma história universal."

${ }^{14}$ LETTIERI, Gaetano. Note sulla dottrina agostiniana delle due ciuitates: a proposito di «Jerusalem and Babylon» di J. van Oort. Augustinianum, 33, 1993, p. 257-307: 281. 
dominicus dies uelut octauus aeternus, qui Christi resurrectione sacratus est, aeternam non solum spiritus, uerum etiam corporis requiem praefigurans. Ibi uacabimus et uidebimus, uidebimus et amabimus, amabimus et laudabimus. Ecce quod erit in fine sine fine". ${ }^{15}$

\section{Delineamentos da fortuna medieval}

A doutrina das seis idades da história registra uma notável difusão no Ocidente cristão, afirmando-se como esquema historiográfico canônico a partir, pelo menos, dos séculos VII e VIII. ${ }^{16} \mathrm{Na}$ primeira metade do século VII, Isidoro de Sevilha, na Chronica minor (a saber, no capítulo "De descriptione temporum" do livro V de suas Etimologias), explica os significados da palavra aetas, precisando que "aetas autem proprie duobus modis dicitur: aut enim hominis, sicut infantia, iuventus, senectus aut mundi etc.", a que se segue uma descrição da doutrina agostiniana. No capítulo XXXIV, Isidoro fornece uma lista detalhada das personagens e dos eventos de cada idade e nota-se o seu esforço para detalhar os eventos da história pagã (a respeito da qual ele se informou por meio de Jerônimo e de Eusébio) e para dar lugar aos fatos da história após a encarnação do Cristo. A mesma observação vale para seu Chronicon, ou Chronica maior. Enquanto Isidoro consagra os capítulos 42-65 à quinta idade, isto é, 23 capítulos, a sexta idade requer $56 .{ }^{17}$ No começo do século seguinte, Beda, o Venerável, retoma a questão em diversas obras. Se o De temporibus liber (703) e o De temporum ratione (725) fornecem uma síntese da doutrina agostiniana, o interesse de Beda por esse assunto é também de ordem autobiográfica. Com efeito, ele fora acusado de ter posto em causa a Encarnação na sexta idade, acusação de que se defende na Epistola ad Plegosinum de sex aetatibus saeculi (708). ${ }^{18}$ As múltiplas referências de Beda ao esquema agostiniano constituem o ato definitivo de "canonização" da doutrina das idades do mundo na cultura medieval. Na sequência, ela é ha-

${ }^{15}$ De ciu. Dei XXII 30, 5. Em De ciu. Dei XVI 24, 2, Agostinho havia mencionado as primeiras três idades como possível referente analógico dos primeiros três animais (bezerro, cabra, áries) sacrificados por Abraão e a doutrina é recapitulada na conclusão do livro (cf. Aí XVI 43, 3).

${ }^{16}$ Cf. GUENÉE, Bernard, op. cit., e SINISCALCO, Paolo. Un modello storiografico fortunato: le età del mondo dall'epoca patristica al Medio Evo (1999). In: Idem. Il senso della storia: studi sulla storiografia cristiana antica, Soveria Mannelli (Cz): Rubettino, 2003 («Armarium», 11), p. 213-60.

17 Cf. ISIDORUS HISPALENSINS. Etymologiarum libri V 38-39, De descriptione temporum (ou Chronica minor). Oxford Classical Texts. Oxford: Ed. W. M. Lindsay, 1911, e ISIDORUS HISPALENSIS. Chronicon. In: PL 83, col. 1017-1058.

${ }^{18}$ Cf. BEDA VENERABILIS. De temporibus liber. CCSL 123C. Ed. T. MOMMSEN-C.W. JONES, 1980, p. 585-611 e o De temporum ratione liber. CCSL 123B. Ed. C. W. JONES, 1977, p. 263-544. 
bitualmente reencontrada nos comentários exegéticos sobre as passagens da Bíblia em que ela estava baseada. Os autores medievais se aplicam igualmente em aperfeiçoar o esquema agostiniano: refazem-se os cômputos das gerações e dos anos de cada idade; trabalha-se a simbólica numérica, ampliando a rede de passagens escriturárias implicadas; por fim, desenvolvem-se os paralelos entre história sacra e história profana que estavam in nuce no De ciuitate Dei sob as figuras das duas cidades.

Contudo, mesmo se universalmente conhecida e hegemônica, a doutrina das seis idades não é de modo algum exclusiva na concepção histórica medieval e tampouco é recebida sem problemas pela tradição posterior. Ela se casa frequentemente, não sem dificuldade, com outros esquemas historiográficos que Agostinho havia propositadamente posto de lado. A teoria dos quatro impérios, por exemplo, que Orósio havia adotado (e manipulado extensamente) a despeito da opinião agostiniana, ${ }^{19}$ mostra-se particularmente obstinada em razão da preeminência das Historiae de Orósio no domínio historiográfico relativamente ao De ciuitate Dei, uma leitura praticada mais pelos teólogos. Também, a despeito do esforço de Agostinho e das hierarquias eclesiásticas para eliminar a tentação milenarista, ela se apresenta de modo regular ao longo de toda a Idade Média. Por último, mas não menos importante, a doutrina agostiniana apresentava um limite incontornável a seus partidários. Como já evidente em Isidoro, à medida que a sexta idade se desenvolve sem um fim, o esquema agostiniano coloca a quem o segue o problema de como fazer a narrativa da era cristã. A busca por elaborar outros esquemas historiográficos, capazes de dar conta da história recente e de suas articulações, sem, contudo, por em questão o esquema recebido da história universal, constitui um dos principais desafios para o pensamento historiográfico do Ocidente medieval. ${ }^{20}$ Os cronistas medievais enfrentam aquilo que se poderia chamar a excrescência da sexta idade seja integrando a matéria moderna nos quadros da sexta idade (como Isidoro), ou então separando essa matéria e destinando-a a crônicas ab incarnatione. As crônicas universalmente

${ }^{19}$ Cf. MARROU, Henri-Irénée. Saint Augustin, Orose et l'augustinisme historique. In: La storiografia altomedioevale. Spoleto: C.I.S.A.M., 1970 ( «Settimane di studio del centro italiano di studio sull'alto medioevo», XVIII), vol. I, p. 59-87. Sobre a dupla herança orosiana e agostiniana na Idade Média, e as tentativas feitas para harmonizá-las, permito-me remeter a BRILLI, Elisa. L'entente entre Orose et Augustin: jalons pour l'histoire de la vulgate culturelle médiévale. In: FERRARI, Michele Camillo (ed.). Orosius im Mittelalter (no prelo).

${ }^{20}$ Cf. BREZZI, Paolo. Il superamento dello schema agostiniano nella storiografia medievale. In: Forma futuri. Studi in onore del Cardinale Michele Pellegrino. Torino: Bottega d'Erasmo, 1975, p. 954-960: 957. 
inspiradas, em seu próprio título, pelo esquema agostiniano são inúmeras, desde as do século IX, como as crônicas redigidas por Claudius, bispo de Turim e pelo arcebispo de Viena, Ado, até a de Walter Odington, ou de Evesham ( $\dagger$ cerca de 1330), um monge beneditino conhecido, sobretudo, por suas pesquisas astronômicas e cuja Summa de aetate mundi permanece inédita. Poderíamos igualmente nos lembrar das obras históricas do dominicano Nicolas Trevet que, no começo do século XIV, pratica livremente as diferentes possibilidades mencionadas, da monografia (com os Annales regum Angliae, que vão de 1135 a 1307), à crônica universal resumida (com a Historia ab origine mundi ad Christum natum) e à crônica universal propriamente dita (com suas Crônicas, que vão da Criação à década de 1340).

Mesmo as obras mais inovadoras não ignoram o esquema agostiniano. A Historia scholastica, de Petrus Comestor, composta cerca de 1170 em Paris, é um resumo de história sacra destinado aos estudantes das faculdades parisienses que conheceu um sucesso duradouro. Sua particularidade é a integração de diversas informações da história profana, tiradas de Flávio Josefo e de outros historiadores antigos, naquilo que Petrus chama de incidentia, isto é, os parágrafos de algumas linhas adicionados ao relato traditional da história sacra. No entanto, Petrus Comestor enfatiza habitualmente as passagens de uma idade a outra por meio de episódios decisivos. E, se é verdade que ele não menciona as seis idades ao percorrer o relato da Criação, ele se refere uma vez a elas quando ele chega à parábola evangélica de Mateus XX, explicitando a dificuldade da interpretação abraçada outrora por Agostinho: "Tunc Dominus proposuit eis similitudinem de patrefamilias, qui conduxit operarios in vineam suam ex denario diurno (Mt. XX). Cumque nonnisi quinque horae diei ibi numerentur, tamen omnes subintelliguntur sex aetates, tam temporis quam hominis. In undecima enim quinta, et sexta aetas, vel chilias intelligitur. In eadem quoque senectus, et decrepita". ${ }^{21}$

Uma outra dimensão em que se percebe a circulação medieval da doutrina agostiniana é a litúrgica. No século XII, as grandes enciclopédias litúrgicas se referem à doutrina agostiniana para explicar as denominações dos quatro domingos do tempo litúrgico entre a Septuagésima e a Quaresma. Deixando de lado os problemas terminólogicos e de cômputo que essas escansões levantam, Rupert de Deutz e João de Beleth afirmam, ambos, que cada domingo comemorava as primeiras quatro escansões da "septenaria distinctio aetatum mundi". ${ }^{22}$ É precisamente

${ }^{21}$ PETRUS COMESTOR. Historia scholastica. Historia euangelica 105. In: PL, 198, col. 1590.

${ }^{22}$ Cf. RUTPERTUS TUITIENSIS. De diuinis officiis per anni circulum, IV, 3. In: CCCM, 7. Ed. R. Haacke, 1967, p. 104. Como exemplo da circulação para além dessas summae, cf. HENRICUS AL- 
essa a tradição que Joaquim de Flora retomará, mas a modificando com base na distinta esquematização que ele propõe para a interpretação da história universal. ${ }^{23}$

\section{Os diagramas do Liber Floridus (cerca de 1122)}

Diante da extraordinária difusão dessa doutrina, as representações iconográficas são, no todo, raras. Um primeiro exemplo é oferecido pelo Liber Floridus, a compilação enciclopédica preparada por Lambert, cônego de Saint-Omer, por volta do ano 1122, e cuja cópia autógrafa se conserva na Biblioteca Universitária de Gand (manuscrito 92). ${ }^{24}$ Lambert de Saint-Omer mostra uma afeição especial pelas seis idades: retomando esse esquema, ele integra sua enciclopédia com uma compilação de história universal, desde a criação até os seus tempos (ff. 23r-46r), cuja última parte, dedicada à sexta idade (ff. 36v-46r), é também conhecida como Annales Audomarenses e contém três representações gráficas sobre este argumento.

A primeira, intitulada Ordo regnorum principaliter regnantium, consiste em uma circunferência, ou rota, ou sphaera, em cujo centro se lê Etates mundi, subdividida em seis segmentos, um por idade (f. 19v; fig. 2, pág. 254). Assim o identificam também as rubricas apostas à circunferência externa, em correspondência com cada segmento, que informam a respeito do regnum hegemônico na idade correspondente, ${ }^{25}$ enquanto, no interior dos segmentos, é colocada uma seleção de informações de história bíblica e pagã. Como indica o título, esse esquema tenta, não sem algumas dificuldades, combinar o esquema agostiniano das idades da história com o esquema da sucessão dos reinos políticos, ao qual

BANENSIS. De peregrinante ciuitate Dei, XIV. In: PL 204, coll. 361-62: «Quod enim initio anni Septuagesimam, dehinc Sexagesimam, Quinquagesimam quoque et Quadragesimama consueuit Ecclesia solemniter celebrare, quatuor primis aetatibus conuenire uidetur». Cf. RUTPERTUS TUITIENSIS. De diuinis officiis per anni circulum, IV, 3. In: CCCM, 7. Ed. R. Haacke, 1967, p. 104.

${ }^{23}$ IOACHIM ABBAS FLORENSIS. Sermo in septuagesima. In: Idem. Sermones. Roma: ISIME, Ed. V. de Fraja, 2004 («Fonti per la storia dell'Italia Medievale. Antiquitates», 18), p. 21-22, 11. 21 ss. E, para maiores esclarecimentos sobre problemas de cômputo, as páginas XXVIII-XXIX da introdução.

${ }^{24}$ Cf. o facsímile, Gand: Albert Derolez, 1968 e as reproduções no sítio http://www.liberfloridus.be/ gent_eng.html. Sobre esse manuscrito, cf. DEROLEZ, Albert. The autograph manuscript of the "Liber Floridus». A key to the Encyclopedia of Lambert of Saint-Omer. Corpus Christianorum Autographi Medii Aevi. Turnhout: Brepols, 1998, em part. p. 45-56.

${ }^{25}$ Em sentido horário, a partir do primeiro, no alto à direita: «Prima aetas mundi ante diluuium fuit»; «II post diluuium fuit his laborantibus»; «III Assyriorum regibus precipue regnantibus»; «IIII Mediorum regibus post regnantibus»; «V Persarum regibus post hos regnantibus»; «VI Romanorum regibus regnantibus». 
se referem também as rubricas apostas aos quatro ângulos do diagrama. ${ }^{26}$ Ele é dedicado inteiramente às Mundi etates usque Godefridum regem, isto é, até a tomada de Jerusalém em 1099, a representação no atual f. 20v (fig. 3, pág. 254). O esquema, inspirado pelo esquema clássico de Beda sobre as fases da Lua, ${ }^{27}$ é composto por duas circunferências, ou rotae, ou sphaerae, a externa tríplice e a interna dupla, em que está desenhado um rosto antropomorfo (segundo a inscrição na borda, o $M V N D V S$ ). Entre as duas cricunferências, são desenhados seis arcos idênticos, todos tangenciais à rota interna e dispostos de modo a se intersecionarem a intervalos regulares, formando pequenos registros ovais cuja junção é evidenciada, do lado da rota maior, por uma cruz e, do lado da menor, por um pequeno círculo deixado em branco. Lendo-se em sentido horário, é fornecida, sobre os arcos, a descrição da duração de cada idade, ${ }^{28}$ enquanto o espaço compreendido entre o arco e a circunferência maior abriga uma seleção de protagonistas e episódios notáveis de cada idade, tirados também da história pagã. ${ }^{29}$ Para além da atualização do esquema receptus até a tomada de Jerusalém, ocorrida então havia pouco mais de vinte anos e à qual Lambert consagra um longo capítulo, ${ }^{30}$ interessa a cultura gráfica dessa exposição da doutrina das seis idades. Os seis arcos que se intersecionam tornam visível tanto a continuidade das idades, enfatizada pela borda vermelha na margem externa, quanto sua sucessão, uma vez que cada arco se sobrepõe ao precedente. Por sua vez, a relação entre circunferência maior e circunferência menor alude à relação entre macrocosmo (as idades da história da humanidade) e microcosmo (as idades da vida individual) a que se referem, respectivamente, o texto que precede o diagrama e aquele que

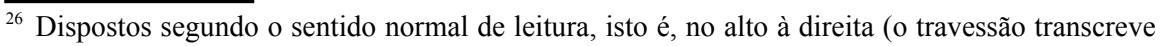
as linhas coloridas que unem as palavras): «Assyria - Ninus rex Assyriorum. Abraham. Media - Arbaces. Idola»; no alto à esquerda: «Hieremias. Cyrus rex persarum - Persida. Grecia Alexander. Synagoga»; embaixo, à direita: «Romulus. Roma. Consul Brutus. Iulius»; embaixo, à esquerda: «Christus. Ecclesia. Cesar Augustus».

${ }^{27} \mathrm{Cf}$. os esquemas reproduzidos em BEDA VENERABILIS. De temporum ratione, I 17 e 24 . In: $P L$, 90, col. 381-382 e col. 399-400.

${ }^{28}$ Ou seja: I. «Prima etas continens annos MCCXLII»; II: «Secunda etas continens annos MCCCCXLII»; III: «Tertiam etas continens annos DCCCCLXXIII»; IV: «Quarta etas continens annos DXII»; V: «Quinta etas continens annos D XLVIII»; VI: «VI etas usque ad captam Hierusalem annos $M X C I X »$.

${ }^{29}$ Transcrevo, a título de exemplo, o conteúdo da primeira («Adam Eua Abel Seth Enos Caynan Malaleel Jared Enoc Matusalem Lamec Noe archam edificans per C annos») e da sexta idades («Octauianus Christus apostoli euangeliste martires confessores uirgines Infra anno domini MXCIX per Godefridus dux cepit Hierusalem inditione VII»).

${ }^{30}$ Capítulo 129: Gesta Francorum Hierusalem expugnantium ff. 110v-128r do autógrafo. Sobre as fontes e o interesse desse capítulo, cf. DEROLEZ. The autograph manuscript of the "Liber Floridus», cit., p. 117. 
se segue a ele. ${ }^{31}$ Esse mesmo aspecto da doutrina agostiniana é valorizado pela terceira imagem do mesmo tema que, perdida no autógrafo, conserva-se nas cópias da assim chamada terceira família, como no chamado manuscrito Gudeanus lat. 1 da Herzog August Bibliothek de Wolfenbüttel (f. 67r; fig. 4, pág. 255) que, datado da segunda metade do século XII, é considerado a origem desse grupo. ${ }^{32}$ As rotae são, desta vez, duas, ambas inspiradas pelo mesmo esquema gráfico originário de Beda. No centro da rota superior, enquadrada por um excerto do tratado pseudo-agostiniano Dialogus questionum, ${ }^{33}$ é retratado um ancião nu e nimbado, alegoria, segundo a inscrição aposta à bordura, do mundus maior et etates seculum. As circunferências mais externas, distintas em compartimentos segundo o esquema já descrito de arcos secantes, dão informações sobre cada idade, combinando o dia da criação com a duração de cada idade, sua denominação e, segundo o sistema de símbolos do sonho de Nabucodonosor (cf. Dn 2, 31-45), o material da parte do corpo corres-pondente no colosso. ${ }^{34}$ Ao ancião mundus maior da rota superior, responde, no segmento central da rota aposta na metade inferior do mesmo fólio, um jovem nu, ou seja (ainda de acordo com a inscrição

${ }^{31}$ Supra: «[rubrica:] Mundi etates usque ad Godefridum regem. / [Linha contínua] Sex etates per sex milibus dicuntur finem facientes in anno domini DCCXLII / [à esquerda do gráfico] etas quod de multis seculis / instruitur dicta est: to/tum tempus uice presen/tis ab initio usque ad finem./ [à direita do gráfico] Isidorus dicit etas perpe/tua est cuius neque/ initium neque/ extremum/nescitur»; infra: «[rubrica] Microsmos. Hoc est minor mundus/ Descriptio Etatis Hominum. Per VII etatis hominis descriptio / [col. a] Infantia usque ad annos VII / Pueritia usque ad annos XIIII / Adulescentia usque ad annos XXVIII / [col. b] Iunentues usque ad annos L / Grauitas usque ad annos $L X X /$ Senectus usque ad annos $L X X X /$ Decrepita usque ad annos finis». A fonte declarada é ISID. HISP. Etym., ed. cit., V, 38, 3-4.

${ }^{32} \mathrm{O}$ manuscrito está inteiramente digitalizado em http://diglib.hab.de/wdb.php?dir=mss/1-gud$\underline{\text { lat\&imgtyp }=1 \& \text { pointer }=0}$. A respeito da perda dessa imagem no autógrafo e da fasciculação original do Liber Floridus, distinta da atual, cf. DEROLEZ. The autograph manuscript of the «Liber Floridus», cit., p. 68.

33 "[no alto, à direita da rota] Augustinus. Omnis creatura antequam tempore suo fieret in ipso dei uerbo prius erat cognoscenda ab angelis [no alto, à esquerda] et sic suo tempore facienda. Tres partes senarii numeri demonstrant domini tante deum in trinitate numeri mensure et ponderis fecisse omnem creaturarum mundi" a comparar com PSEUDO-AUGUSTINUS. Dialogus Quaestionum, resp. XXVI, PL 40, coll. 741-742, sobre o qual, cf. MACHIELSEN, Jan. Clavis Patristica Pseudoepigraphorum Medii Aevi. 2A: Opera theologica, exegetica, ascetica, monastica, Pars A. Praefatio, Theologica, Exegetica. Turnhout: Brepols, 1994, nº 151 e DEKKERS, Eligius. Clavis Patrum latinorum. 3 éd. Turnhout: Brepols, 1995, $\mathrm{n}^{\circ} 373 \mathrm{a}$.

${ }^{34}$ Transcrevo, a título de exemplo, o conteúdo da primeira idade ( «[1 $1^{\mathrm{a}}$ circunferência a partir de fora] Die primo deus angelos condidit. [2 $2^{\mathrm{a}}$ circunferência] Mundus etate prima caput habens au - $\left[3^{\mathrm{a}}\right.$ circunferência $]$ - reum hora prima apparuit in infantia usque ad Noe annis bis mille ducentis quadraginta duobus perdurans») e da sexta idade ( $\left(1^{\text {a }}\right.$ circunferência a partir de fora $]$ die $V I^{\circ}$ animantia terre et Adam condidit. [2 $2^{\mathrm{a}}$ circunferência] Mundus etate VI hora XI pedes habens [ $3^{\mathrm{a}}$ circunferência] de luto fictiles in etate decrepita uenit et usque ad dei iudicium soli domino cognitum in fine mundi uenturum perseuerabit»). 
posta na bordura central do segmento central), o Mundus minor id est homo et etates eius cum elementis mundi quod nulla concessa est requies. Também esse segundo esquema é circundado por excertos agostinianos e pseudo-agostinianos dedicados à crítica das doutrinas clássicas dos elementos e à Ressurreição. ${ }^{35} \mathrm{Em}$ consonância com esses excertos, os compartimentos da rota associam cada idade com o elemento e com a estação que melhor lhe correspondem. ${ }^{36}$

$\mathrm{Na}$ doutrina das seis idades representada por Lambert, surpreende a extraordinária versatilidade que permite combiná-la com esquemas de outra extração e até mesmo com esquemas aos quais a formalização agostiniana pretendia ser uma alternativa (como no caso dos reinos mundanos). Ademais, a representação gráfica predileta de Lambert, a rota, assim como o referente para o qual fora originalmente elaborada, as fases da Lua, veicula a impressão de uma perfeita continuidade e até mesmo sugere o retorno do tempo sobre si mesmo. Isso era completamente estranho a uma doutrina desenvolvida na polêmica contra a tese estóica do eterno retorno do idêntico; essa polêmica não tinha, entretanto, mais nenhuma razão de ser no horizonte cultural de Lambert de Saint-Omer e ele se volta à rota como a uma forma perfeita, preocupando-se pouco com as sugestões potencialmente heterodoxas que essa escolha morfológica podia veicular. $\mathrm{O}$ caso não é tampouco isolado. Com uma despreocupação análoga, a mesma solução gráfica será adotada, no último quarto do século XIV, pelo iluminador de um exemplar da versão catalã em prosa do Breviari d'amor, de Matfre Ermengau (fig. 5, pág. 255). ${ }^{37}$ A Taula de les Vi edats del mon, como se lê na rubrica que a intitula, compõe-se de duas circunferências concêntricas na borda, nas quais estão indicadas as durações de cada idade (na maior, em sentido anti-horário: De Adam

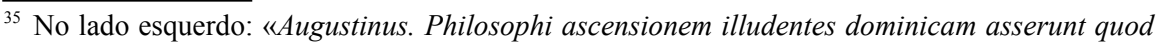
elementorum ordo non sinit ut elementum secundum quod est aqua feratur super aerem elementum, tertium neque hoc qui de terra est supra quartum quod est ignis; ut hoc et aqua sic super celum dicentes uerum esse quod aqua cedit terre et aer aqua et ignis aeri. Sed Dei potentia terre animalia uolitare in aerem et aqua super aerem et ignem intra et hominem terre facit super celos esse», ou seja, uma adaptação sintética de De civ. Dei XXII 11 (especialmente 1), para o qual não me foi possível encontrar uma fonte medieval específica. No lado direito: «Augustinus. Vnde euidenter ostenditur hominem non tantum cum carne et ossibus sed etiam cum sanguine et quicquid ad naturam eius pertinet resurget sed sine ulla corruptione erit illi eterna uita eterna salus eterna uita eterna felicitas in celis contemplando de ciuitate Deum». In: PSEUDO-AUGUSTINUS. Dialogus Quaestionum, resp. XX, PL 40, col. 739-740.

${ }^{36}$ Transcrevo, a título de exemplo, o conteúdo da primeira («Prima etas hominis infantia est usque ad annos VII et ver humidum uernans in etate primeua floridum») e da sexta idade («Sexta etas hominis decrepita estusque ad fienem uite eius et elemento terre digne comparandus»).

${ }^{37}$ Londres, British Library, Yates Thompson 31, f. 77r. Essa miniatura foi citada por SMALLEY, Beryl. Historians in the Middle ages. Nova Iorque: C. Scribner's Sons, 1974, p. 30.
} 
tro a Noe comptam MDCCXL ayns etc.) e os dez mandamentos (na menor, em sentido horário: No auras Deus estrayns, ne aoraras idoles etc.) Entre as duas circunferências, encontram-se seis compartimentos que representam (em sentido anti-horário) os espisódios distintivos de cada idade, a saber: Adão e Eva no ato de cobrirem sua nudez, uma vez expulsos do paraíso terrestre (aqui, um castelo); Noé na vinha; o sacrifício de Isaac; Moisés e Aarão com as tábuas da lei; Salomão entronado que indica um ídolo em um templo: a Virgem com o Menino, em um trono, ao lado de uma igreja em que está figurado o momento de elevação da eucaristia. Na circunferência interna, por sua vez, está representado um anjo com os braços erguidos e abertos que, segundo a rubrica, muda los tempos e les edats, com atitude absolutamente análoga à tipologia iconográfica mais laica da Fortuna. ${ }^{38}$

\section{A cristologia da história da Winchester Bible (cerca 1160-1175)}

Totalmente diverso é o tratamento desse assunto na assim chamada Winchester Bible, a grande bíblia iluminada realizada em Winchester entre 1160 e 1175 e conservada na Biblioteca Catedralícia dessa cidade. O "I" historiado no início, característico das bíblias românicas, não abriga, como é habitual, uma representação das obras da criação, mas sim sete medalhões, figurando os momentos proeminentes de cada uma das idades da história universal (f. 5r, fig. 6, pág. 256). Os medalhões representam, na ordem: a criação de Eva a partir da costela de Adão, significando aqui toda a criação e a primeira idade; a arca de Noé, símbolo costumeiro da segunda idade; o sacrifício de Isaac; a entrega das tábuas da lei a Moisés; a unção real de Davi; a natividade; e, por fim, a segunda parousia do Cristo. ${ }^{39}$

A substituição das mais habituais obras da criação pelas idades da história se compreende facilmente à luz do nexo tipológico fixado pela exegese agostiniana entre uma e outra. Inaugurando o texto da Gênesis, a letra historiada já evoca os significados tipológicos daquela narrativa e convida a discernir no que se lerá a prefiguração da história universal, para além de todo o decurso narrado no resto da Bíblia. Por sua vez, a seleção dos episódios representados por cada idade parece responder a parâmetros precisos. Por um lado, certamente o iluminador

${ }^{38}$ Cf. WIRTH, Jean. L'iconographie médiévale de la roue de la Fortune. In: FOEHR-JANSSENS, Yasmina e METRY, Emmanuelle (eds.). La Fortune. Thèmes, représentations, discours. Genebra: Droz, 2003, p. 105-27.

${ }^{39}$ Cf. OAKESHOTT, Walter. Sigena. Romanesque paintings in Spain and the artists of the Winchester Bible. Londres: Harvey Miller \& Medcalf Ltd, 1972, p. 107 e ss.; Idem. The two Winchester Bibles. Nova Iorque: Oxford University Press, 1981 e DONOVAN, Claire. The Winchester Bible. Toronto e Buffalo: University of Toronto Press, 1993, p. 34-35. 
deu preferência a temas amplamente codificados e que integravam seu repertório, ou seja, para dizer a mesma coisa em outros termos, temas extremamente fáceis. Ao mesmo tempo, essa seleção evidentemente dá preferência, entre os assuntos à disposição, àqueles cujo valor é mais claramente cristológico. A composição axial da letra historiada potencializa essa leitura, de modo que a superposição vertical dos medalhões apresenta o decurso histórico como suceder-se de typoi Christi até os dois momentos críticos da encarnação e, epílogo último, do juízo final.

\section{0 De civitate Dei de Santa Maria de Bosav}

O último exemplo a ser considerado é, ao mesmo tempo, o mais complexo e o menos conhecido. Trata-se de uma suntuosa dupla página iluminada de um $D e$ ciuitate Dei realizado na segunda metade do século XII, no mosteiro beneditino de Bosau (ou, segundo a toponímia medieval, Buzowe, Puzowe, Pozowe), perto da atual cidade de Zeitz, a cerca de quarenta quilômetros a sudoeste de Leipzig. O mosteiro de Santa Maria de Bosau foi fundado por iniciativa do bispo de Naumburg, Dietrich I († 1123), como posto avançado em uma região majoritariamente eslava. A construção foi iniciada em 1114; consagrado em 1121, o claustro é, desde o começo, associado à abadia de Hirsau, de onde provém o primeiro abade, Ekkebert I. A fundação é imediatamente dotada de posses notáveis, incrementadas ulteriormente por doações de nobres que se multiplicam após o mosteiro obter a proteção real (em 1160). Um documento de 1167, conservado no arquivo diocesano de Naumburg, inclui, nessa data, Atto I (que reencontraremos em breve), o prior Konrad, futuro sucessor de Atto, doze presbíteros, seis diáconos e onze subdiáconos, sugerindo, assim, quando se pensa nos simples monges e nos leigos não citados, que o mosteiro podia contar setenta ou oitenta membros. No momento de sua fundação, o mosteiro também é dotado de um scriptorium, de onde se conhecem pelo nome pelo menos três copistas que tinham o feliz hábito de assinar seu trabalho: Luthelm, ativo nos meados do século XII; Erkenbertus, sob a direção do qual o scriptorium conhece seu apogeu; por fim, Symeon, aluno do precedente, que dá continuidade ao trabalho de Erkenbertus até o fim do século XII. Sua atividade parece destinada principalmente ao uso interno, uma vez que não se encontram manuscritos copiados em Bosau em bibliotecas outras que a do próprio mosteiro. Essa, cujo núcleo originário provém provavelmente de Hirsau, respeita os cânones das bibliotecas monásticas da época. No catálogo curado por Renate Schipke, há vinte e quatro manuscritos anteriores ao século XIII: para além dos textos escriturais (uma Bíblia e um salterio) e de estudo (um Prisciano), a maior parte dos manuscritos contém obras exegéticas dos pais da Igreja (o 
comentário aos profetas menores de Jerônimo; os de Ambrósio e de Agostinho aos salmos; de Gregório sobre o Cântico dos Cânticos e sobre o Evangelho de João, assim como as Moralia in Iob e os Diálogos), a que se somam dois textos históricos (as Historiae aduersos Paganos, de Orósio, e as Antiquitates, de Flávio Josefo, este último incompleto). ${ }^{40} \mathrm{O}$ manuscrito do De ciuitate é, sem dúvida, o mais luxuoso da biblioteca no século XIII. ${ }^{41}$

Depois do excerto das Retractationes II 43 (nos ff. 1r-v), que serve habitualmente de prólogo ao De ciuitate Dei, e antes do incipit do texto (no f. 4r), são inseridas duas composições originais: uma carmen de 28 versos leoninos, que se conclui com o habitual anátema contra quem tentar se apoderar do manuscrito e que dá indicação do nome do copista, Erkenbertus, e do abade Atto (de onde se extrai a datação de entre 1168 e 1180 , cf. F. 1va), ${ }^{42}$ e uma outra composição de 30 versos, com todas as rimas em - antur, que serve de introdução à dupla página seguinte (f. 2r). Esta carmen convida a se considerar com atenção as iluminuras e seus significados místicos; ela identifica o seu assunto como as cidades místicas da Babilônia e de Jerusalém e suas vicissitudes respectivas (v. 1-5); retoma a doutrina das seis idades (v. 6-12), referindo-se tanto às idades da vida individual quanto à parábola evangélica (v. 13-24). Por fim, conclui-se com uma dúplice exclamação sobre os destinos dos danados e dos beatos no outro mundo (v. 25-30). ${ }^{43}$ Segue-

${ }^{40}$ Cf. SCHIPKE, Renate. Scriptorium und Bibliothek des Benediktinerklosters Bosau bei Zeitz: die Bosauer Handschriften in Schulpforte. Wiesbaden: Harrassowitz, 2000, p. 13-44.

${ }^{41}$ Pforta, Bibliothek der Kgl. Landes-Schule, ms. lat. A 10. Membr.; mm. 363 x 236 (mm. 275 x 160); ff. II, 289, I'; 2 coll.; $42-45$ 11. Cfr. FREYTAG, Friederich G. Dissertatio de codice membranaceo exarato, qui Augustini libros de Civitate Dei complectitur, in bibliotheca Portensi. Lipsiae 1747 (riprodotto in: Adparatus litterarius, ubi libri partim antiqui, parti rari recensentur collectus... Lipsia: ex officina Weidmanniana, 1752-1755, 3 vol. in-12 ${ }^{\circ}$, vol. 2); LABORDE, Alexandre de. Les manuscrits à peinture de la Cité de Dieu de saint Augustin. Paris: E. Rahir, 1909, 3 vol., vol. I, n. 2, p. 218-25, imagens II e III; JASBAR, Gerald. Darstellungen antiker Götter im Ms. A. 10, (Augustinus, De civitate Dei) der Bibliothek der Oberschule in Schulpforte $(D D R)$. Inaugural-dissertation zur Erlangung des Doktorgrades der Philosophie an der LudwigMaximilians-Universität zu München, 1980; SCHIPKE, Renate. Scriptorium und Bibliothek, cit., p. 62-66; WITTEKIND, Susanne. Die Illustration von Augustinustexten im Mittelalter. In: GEERLINGS, W. e SCHULZE, Chr. (eds.). Der Kommentar in Antike und Mittelalter. Leiden: Brill, 2002-2004, 2 vol., vol. 2, 101-127: 121-126.

${ }^{42}$ Vv. 21-28: «[...] ... faveas, o Christe, labori // respiciasque pia/ tibi reddita vota, maria. // Hec Erkenbertus/spe firmus et hac ope certus // stella Maria maris/ tibi vovit, que tuearis // qui tibi tollit ea, / fur, raptor hic est anathema, // et ni reddat ea, dampnetur sore suprema, // Et pater Azzo bonus/in vota favendo patronus // dignus mercede/ requiescat perpete sede. // Amen».

${ }^{43}$ «Aspice! picta vides; his mistica significantur! / En Babilon et Ierusalem simul edificantur. / Iustis iniustis hae civibus amplificantur / et sex etatum per tempora multiplicantur / et, mutando vices, alternatim variantur. / Primi sunt ab Adam; sic ad Noe dinumerantur; / per Noe rursus ad Habhram reliqui sociantur; / ad David Habhram mittit qui lege ligantur; / a David exerunt donec Babilone migrantur; / ad Christum tendunt qui de Babilone vocantur; / post Christum 
se a dupla página iluminada (ff. 2v-3r), que opõe a ciuitas dei à ciuitas diaboli, articulando suas respectivas histórias nas seis idades. ${ }^{44}$ Ambas as miniaturas estão contidas em uma moldura que imita uma muralha e articuladas em seis compartimentos regulares (dois compartimentos em cada um dos três registros), além de um último registro, organizado diversamente em cada ciuitas. A estruturação da dupla página iluminada responde a um princípio geral de simetria diferenciativa, como veremos. Para comunicar o conteúdo desse dispositivo, eu forneço uma decrição paralela dos assuntos de cada miniatura, mantendo em mente que a identificação é facilitada pelas indicações destinadas ao iluminador que se conservaram nos fólios de guarda do manuscrito (ff. IIr-IIv; fig. 7 e 8 , págs. 257 e 258). ${ }^{45}$

veniunt baptismate qui renovantur; / sabbata succedunt sic omnia fine rotantur. / Qui sex etatum sub temporibus titulantur, / hi vitis verae cultore esse probantur / sexque laborantes horis, in ea spatiantur. / Hi quoque denario donati glorificantur, / qui pueros, adolescentes, iuvenes imitantur / quique viros, seniores, decrepitos venerantur / ut paribus mercede pari pariter potiantur. / Sero licet undecima vel nona sepe citantur / qui primi medii sexti perinane vagantur, / hiique labore prioribus aliis (?) mediis reputantur / in quos primorum non murmura iusta notantur / et primis mediis ex denario simulantur. / O quam felices si tales inveniantur / qui celi patriae digni cives habeantur! / Heu Babilon cives in Tartara precipitantur / Et miseri sine fine sui flammis cruciantur ! / Christe, coeredes non ista tui patiantur / Sed te perpetua domino cum pace fruantur !». Agradeço a Gisèle Besson por seu auxílio na transcrição destes versos.

${ }^{44}$ Cf. o explicit, em que se lê: «Explicit liber sancti Aurelii Augustini Ypponensis episcopi .XX.II.us de ciuitate dei, qui est unus de debitis finibus utriusque ciuitatis dei et diaboli, feliciter. Amen. Amen. Amen» (f. 289r). Eu lembro aqui que, na Idade Média, a definição da ciuitas diaboli se impõe àquela, mais frequentemente usada por Agostinho, de ciuitas terrena.

${ }^{45}$ Essas indicações são escritas ao longo daquela que viraria a moldura dos compartimentos, a partir do lado esquerdo, seguindo para o lado superior e, por fim, ao direito. Um travessão ou um ponto final separam a menção de um tema da menção seguinte. O texto das indicações está escrito em escrita cursiva, precedido de um asterico após a descrição de cada compartimento (a crux indica as palavras ou parte de palavras ilegíveis; o travessão indica a separação dos assuntos). Alexandre de Laborde observava: "O que devemos pensar dessas duas páginas? Devemos crer que, em uma época não determinada, os monges tenham sentido necessidade de se dar conta do significado das pinturas do manuscrito, que lhes escapava, e que eles tenham atribuído a um deles a tarefa de lhes explicar, nesses quadros, a explicação das iluminuras? Nesse caso, deveríamos nos surpreender por um fólio ter sido primitivamente preparado para isso. Ademais, perguntamos por que o escriba teria deixado em estado de rascunho a redação desse trabalho ao invés de passá-la a limpo e de lhe dar uma forma mais bem cuidada e mais digna de figurar em um manuscrito dessa importância. Nós devemos antes reconhecer que essas duas páginas constituem o rascunho original da personagem que havia encomendado o trabalho e o tema que ele oferecia ao artista, a fim de que esse entrasse bem, graças a esse programa, no espírito do sujeito a quem se confiava a execução." (LABORDE, op. cit., vol. I, p. 218-9). Acrescentemos outras observações que conduzem à mesma conclusão. Acima de tudo, as diferenças que se encontram entre o rascunho e as iluminuras (por exemplo, a respeito do posicionamento dos pés de Cristo na ciuitas Dei), que se explicam mal, se o esquema tivesse sido traçado com base nas iluminuras, mas que se explicam muito bem como revisões ou modificações do projeto inicial em processo de realização. Secundariamente, a oportunidade dessas indicações, caso o manuscrito, projetado e redigido em Bosau por Erkbertus, tivesse sido enviado alhures (por exemplo, a Hirsau) para ser 
Essas duas páginas iluminadas constituem um portentoso projeto de síntese iconográfica sem paralelos na tradição do De ciuitate latino e que, a julgar pelos documentos conservados, não parece ter tido nem modelos precisos nem herdeiros. Na dupla página de Pforta, impressiona a simetria global. As duas iluminuras são articuladas de modo a parecerem especulares, distinguindo-se, e mesmo opondo-se, apenas em um segundo exame. A moldura arquitetônica é idêntica, formal e cromaticamente, e, mesmo que esse tipo de moldura seja frequente nas iluminuras românicas, não se pode duvidar de que muros, portas e colunas sejam aqui depositárias de um sentido específico, como tradução visual da imagem mental da ciuitas. Confirmam-no a cena do assassinato de Jorão com o detalhe do cavalo de sua carruagem, que saiu de uma das portas da moldura. Toma corpo, assim, o topos da expulsão, aquela dos ímpios, expulsos da comunidade dos justos, e a coincidência entre transgressão literal e metafórica confirma o valor da moldura como limen funcional que conota o espaço que ele delimita como ciuitas.

Em ambas as molduras, encontram-se duas séries de medalhões que acolhem, na cidade de Deus, diversas espécies animais (exceto o caçador do medalhão XIII) e, na outra, o panteão das divindades pagãs. É pouco nítida a lógica estruturante da seleção e disposição dos assuntos, dos quais alguns são, contudo, certamente não casuais, ${ }^{46}$ mas interessa sobretudo o sentido estrutural da contraposição. Ela remete à antonomia teológica entre criaturas (os animais) e falsos criadores (as divindades) e, em uma etapa sucessiva, à acusação corrente contra os pagãos de confundirem as primeiras com as segundas, ou seja, ao desconhecerem o único criador, os pagãos transformariam as criaturas em divindades, o que consiste no pressuposto da idolatria, segundo a formulação paulina na epístola aos romanos: "et coluerunt atque servierunt creaturae potius quam Creatori, qui est benedictus in saecula". E lembrar-se-á que Agostinho cita essa passagem em um dos pontos mais célebres de seu desenvolvimento sobre as duas cidades, a síntese ao fim do livro XIV.${ }^{47}$ As criaturas, na moldura da ciuitas dei, em uma posição liminar que confirma sua subordinação ao homem na hierarquia da criação, voltam-se quase

iluminado segundo um programa definido justamente em Bosau (razão talvez da conservação do rascunho).

${ }^{46}$ Por exemplo: o leão sobreposto à maiestas divina, ecoando a soberania desta; provavelmente o caçador do medalhão oposto, no lado inferior da moldura, para o qual eu não sei, contudo, oferecer uma explicação precisa; o Jano do primeiro medalhão da ciuitas diaboli, talvez reminiscência do Janus que inicia os calendários; Júpiter e Netuno, os dois soberanos do panteão pagão, que se refletem um ao outro nos dois medalhões centrais da margem superior e inferior da moldura.

${ }^{47} R m$ 1, 25 e cf. De civ. Dei XIV 28. 
todas ao centro, como que prestando homenagem ao Cristo; os medalhões dos deuses, na iluminura de fronte, constituem, por sua vez, outros centros de gravidade de uma imagem que é desprovida de centro. ${ }^{48}$ Eu tampouco excluiria uma alusão à arca de Noé, motivada pela interpretação corrente dessa última como imagem da ciuitas dei peregrina, como, por exemplo, em De ciuitate Dei XV, 26: "procul dubio figura est peregrinantis in hoc saeculo ciuitatis Dei, hoc est Ecclesiae, quae fit salua per lignum, in quo pependit "Mediator Dei et hominum, homo Christus Iesus" (1 Tim 2, 5).

O princípio de homologia macroestrutural é respeitado pela articulação interna das duas iluminuras, que é a tradição figurativa da doutrina das seis idades da história. Característica da dupla página de Pforta é a extensão dessa partição a fatos e personagens da história pagã, segundo o desenvolvimento medieval das premissas agostinianas, sobre o qual já discorremos acima. Também o sistema de relações que conecta a moldura aos compartimentos, caracterizado por um princípio de simetria. Em ambas as iluminuras, são representadas as duas cidades de Babilônia e de Jerusalém e, mais precisamente, os momentos de construção de uma (segunda idade da ciuitas diaboli) e de reconstrução da outra (quinta idade de ciuitas dei). A tensão entre Babilônia e Jerusalém, referentes antonomásticos das duas cidades, traça assim uma diagonal imaginária que atravessa a dupla página, complexificando a oposição frontal das duas cidades por meio de uma especificação consistente.

Nessas imagens globalmente simétricas, são inseridos elementos próprios apenas a uma das duas, elementos excessivos relativamente à estrutura comum. $\mathrm{O}$ excesso da ciuitas dei é, como não poderia deixar de ser, o Cristo. Os cinco medalhões que representam suas extremidades são o excedente com relação à estrutura elementar da imagem e, ao mesmo tempo, inseridos, eles se tornam os elementos que a caracterizam e a constituem em sentido tanto visual quanto alegórico. Essa estrutura reconduz imediatamente à metáfora corrente, e caríssima a Agostinho, da cidade de Deus como corpus Christi. Como termo de comparação, além do célebre mapa-múndi de Ebstorf, pode-se considerar uma das iluminuras de página inteira de um exemplar do tratado anônimo De laudibus de Sanctae Crucis, copiado em Prüfening, perto de Ratisbona, em época próxima do nosso (entre 1170 e 1175): da cruz-árvore encravada na boca do dragão, e cujo centro abriga um medalhão da Virgem, floresce a geração dos eleitos, distintos, como esclarecem as rubricas e, como de costume, profetas, apóstolos, mártires etc. (fig. 11, pág. 256). O

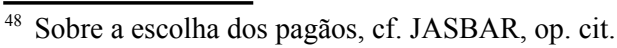


Cristo esqueleto da imagem, e não apenas protagonista do sexto compartimento e idade em que ele é esperado, vale como índice da corrente interpretação cristológica da história veterotestamentária que aqui desemboca em uma tradução visual muito mais radical do que aquela sugerida pela Bíblia de Winchester.

A ciuitas diaboli, por sua vez, não é definida apenas por via negativa, pela ausência do Cristo. Certamente, alguns assuntos são comuns às duas iluminuras e apenas o contexto esclarece os seus valores positivo ou negativo: soberanos, caçadores, cavaleiros e construções estão presentes em ambas e são formalmente idênticas, e apenas o fato de se encontrarem em uma ou em outra declara a sacralidade da reconstrução de Jerusalém e a impiedade da de Enoch e da Babilônia; santa a perseguição de Jorão contra Jéu e nefandas as de Lamech, Nemrod, Ismal e Esaú; sagrado o poder real de Davi e de Salomão, mas celerado o dos soberanos da cidade antagonista. A especificidade da ciuitas diaboli: seu excesso reside no fato de que, nela, esses assuntos se multiplicam de maneira exponencial. Em suma, o próprio da cidade negativa são a redundância e o pleonasmo que configuram a sua história como um retorno contínuo e quase como uma coação a repetir construções, dominações, perseguições e violências. Como se notou com justeza, e as palavras se aplicam perfeitamente à iconografia elaborada em Bosau, "a história da ciuitas hominum é, para Agostinho, uma perpétua repetição do gesto de Caim, enquanto a história da ciuitas Dei comporta uma novidade, isto é, um significado de cumprimento cada vez maior, até a parousia". ${ }^{9}$

Os traços excedentes de cada iluminura configuram, portanto, sua relação nos termos da oposição do um ao múltiplo, de um todo unitário e hierarquicamente ordenado a um cúmulo fracionado e repetitivo. Dessa oposição fundamental, as duas miniaturas de Bosau desenvolvem a estrutura das declinações. Esquematicamente: monoteísmo x politeísmo e heresia (no que respeita à referência aos nicolaítas); a história do povo eleito $\mathrm{x}$ as histórias dos povos (no sentido medieval de gentes); a unidade da verdade revelada da Escritura $\mathrm{x}$ a pluralidade e a contraditoriedade das doutrinas pagãs. Esta última declinação é desenvolvida no último registro. As duas séries de auctoritates - na ciuitas Dei: São Paulo, São João e o anjo escriba; na outra, Varrão e, aos seus lados, a dupla parelha de Platão e Apuleio e de Hermes Trimegisto e Virgílio - encarnam dois cânones culturais opostos. A oposição se exprime também formalmente na maneira distinta de representar os fólios deixados em branco nas mãos das personagens: os de

${ }^{49}$ LEONARDI, Claudio. Agostino e il Medioevo. Una lettera di Gregorio VII a Ermanno di Metz. In: CAVALCANTI, Elena (ed.). Il «De civitate Dei». L'opera, le interpretazioni, l'influsso. Roma: Herder, 1996, p. 361-6: 363. 
São João e de São Paulo convergem em direção ao anjo escriba, e os dos sábios pagãos são retratados como divergentes e centrífugos.

No entando, se a macroestrutura da imagem é fielmente agostiniana, a seleção dos episódios não segue, contudo, o De ciuitate Dei. Neco, Jéu, Jorão, Jônatas, Bacchides, Artaxerxes e Cambises não são citados no tratado. Tampouco o diácono Nicolau (que Agostinho cita em De haeresibus V), enquanto Jeroboão é apenas brevemente referido em De ciuitate Dei XVIII 27. Voltando-se a outros textos medievais que ilustram o decurso das seis idades, muito embora os vários personagens se encontrem mencionados, não pude constatar entre os textos que consultei nenhum que apresente a mesma seleção. $O$ fato interessa não tanto para a individuação de uma fonte específica (e é lícito supor que o conceptor da imagem não tivesse necessidade de uma tal fonte), mas porque ele é exemplar do funcionamento das duas ciuitates e da doutrina das seis idades da história: elas fornecem o esquema geral em que se podem classificar informações de proveniência diversa. Trata-se, de modo não diverso do que se notou para os diagramas do Liber Floridus, de um eficaz instrumento de organização e de gestão dos saberes, isto é, de uma construção de caráter mnemotécnico. A rubrica - quase uma advertência - posta sobre a miniatura da ciuitas Dei explicita essa função, advertindo que os assuntos representados servem também para evocar aqueles não representados, mas presentes na mente do observador: "Hic sex etatum distinxi municipatum regia quo celi completur ciue fedeli. Nomine paucorum numerum uideas reliquorum, hic Michael, Adam uel Abel, Seth, Enos numerantur; Noe, Sem, Iafeth, Nachor, Thare commemorentur; post Abraham vel Ysaac, Jacob Moysesque praebantur".

Nessa visualização, surpreende, ademais, a relativa falta de interesse pela substância apocalíptica e escatológica das doutrinas das duas cidades e das seis idades da história. Essa dimensão, claramente indicada pela carmen que introduz as iluminuras, torna-se secundária no tratamento iconográfico. Nesse sentido, é significativo que o único assunto apocalíptico, o combate do arcanjo Miguel contra o dragão, seja inserido não em uma leitura escatológica, mas em relação com a queda dos anjos rebeldes, chamada a figurar a própria gênese das duas cidades. O sexto compartimento da mesma imagem contém, conceitualmente, em virtude da retomada da distinção canônica das divisões da ciuitas dei, uma alusão ao seu triunfo celeste; nenhum elemento icongráfico, no entanto, vai nesse sentido, e, ao lado tanto de São João Batista como de São Pedro, encontram-se elementos absolutamente terrestres. O modo mais eficaz de "fazer ver" o que eu pretendo é reconsiderar a articulação global das duas imagens: se os primeiros seis compartimentos correspondem às seis idades da história, é lícito esperar que, no sétimo, esteja retratada a sétima idade; em seu lugar, encontram-se, contudo, 
as duas fileiras de auctoritates escriturais e pagãs, literalmente o fundamento e as pilastras de uma e de outra cidade. Paralelamente, e referindo-se agora à atualidade, as duas cidades de Bosau são, para assim dizer, "de manual”. A seleção dos episódios para no século IV da era cristã e, à exceção dos anacronismos de vestimentas e atributos e da referência ao ambiente monástico que se pode inferir da escolha do nicolaísmo, os sete séculos de história que separam São Martinho e Santa Inês (os pontos cronologicamente mais avançados entre os assuntos representados) do momento de realização deste manuscrito não deixam qualquer traço. Bem diversamente do tratamento atualizante usque ad Godefridum regem proposto pelo segundo diagrama do Liber Floridus, o De ciuitate Dei de Bosau apresenta uma mise en image de certo modo arqueológica e filológica, o que se compreende bem em uma representação elaborada não, como no caso da enciclopédia de Lambert de Saint-Omer, para ilustrar uma doutrina que se supõe perenemente válida, mas antes para introduzir o texto fundador em que aquela doutrina estava definida. As duas miniaturas do manuscrito de Bosau apresentam o tratado agostiniano como uma suma historiográfica e enciclopédica, cujo sumário é distinto nos dois blocos paralelos, mas axiologicamente não equivalentes, de estória e cultura sagrada e de história e cultura pagã.

$$
* * *
$$

As visualizações das seis idades da história oferecidas pelo Liber Floridus, pela Bíblia de Winchester e pelo De ciuitate Dei de Bosau mostram, sobretudo, a extraordinária difusão dessa doutrina que, do norte da França ao sudeste da Inglaterra e até a Saxônia, encontra um favor indiscutível no decurso do século XII. O sucesso deriva, em boa parte, da riqueza e da flexibilidade do esquema recebido, cujos fundamentos escriturais, cuja aplicabilidade ao presente e cuja capacidade enciclopédica são a cada vez enfatizadas pelas imagens.

As imagens não deixam, ademais, de conjugar tal esquema com esquemas de extração e de significados diversos. A árdua tentativa de Lamber de Saint-Omer de combinar o esquema dos quatro impérios, dos elementos e das estações com o das seis idades responde justamente a uma instância de síntese e de acordo de auctoritates diversas, mas igualmente irrenunciáveis, que atravessa toda a tradição cultural medieval. Em particular, a dimensão mnemotécnica é claramente perceptível nessas imagens que, até nos casos de elaboração iconograficamente mais complexa, não dissimulam o esquematismo numérico que as estruturam. Nisso se manifesta também a dimensão e a função mnemotécnica da doutrina das seis idades, claramente perceptível também nas imagens em que a elaboração iconográfica se torna mais complexa. 
Por outro lado, não se pode deixar de notar que, à exceção da dupla página do De ciuitate Dei de Bosau, nenhuma imagem das seis idades se refere às duas cidades agostinianas. Essa ausência reflete muito bem um ponto crucial da recepção medieval: a doutrina das seis idades e a das duas ciuitates, ambas conhecidíssimas, tendem, na Idade Média, a circular de modo independente, e isso apesar do nexo estreitíssimo que existia entre elas na concepção de Agostinho. A razão pode talvez ser atribuída à própria estruturação dos livros de história universal no De ciuitate Dei, que, ricos de analepses e prolepses narrativas e trabalhados por digressões contínuas, prestavam-se muito mal à síntese que, consequentemente, apoiou-se em outros trechos de Agostinho, com o efeito de desarranjar a construção que este havia penosamente amarrado.

Por fim, não deixa de surpreender a variedade de soluções morfológicas desenvolvidas pelos iluminadores. Os poucos exemplos discutidos aqui de visualização das seis idades oferecem, em um arco cronológico propositadamente restrito apenas ao século XII, um catálogo extraordinário de formae: das rote do Liber Floridus (e de exemplos posteriores) à construção axial do "I" historiado da Bíblia de Winchester até os dispositivos mais complexos de sentido e de leitura empregados na dupla página do De ciuitate Dei de Bosau. A indubitável universalidade da teologia da história agostiniana e da doutrina das seis idades no Ocidente medieval não exclui, assim, uma multiplicidade morfológica interna no que respeita ao modo de conceber e, portanto, de representar o seu conteúdo e os seus objetos. Paralelamente e para além da repetitividade e da relativa inércia da tradição textual nesse ponto, e de seu repertório estável de citações que se transmitem de texto em texto, as imagens materiais revelam uma surpreendente multiplicidade, se não instabilidade, de formas, sugerindo que a universalidade superficialmente aparente foi possibilitada justamente pela relativa liberdade de concepções e aplicações específicas. 


\section{As seis idades da Civitas Dei}

(f. 2v; fig. 9, pág. 259)
As seis idades da Civitas Diaboli

(f. 3r; fig. 10, pág. 260)

Na iluminura da ciuitas Dei, do f. $2 \mathrm{v}$, cinco medalhões figuram as extremidades do corpo do Cristo: a cabeça («maiestatis» segundo a indicação do f. IIr), as duas mãos (no esquema, entrevê-se a indicação da mão direita), os dois pés (que, segundo as indicações, estavam previstos em um único medalhão, em forma de crucifixo, de modo a fazer coincidir os eixos centrais da iluminura com os eixos da cruz).

\section{0 medalhões [córnice, do alto à direita, em sentido horário]}

1. galinha, 2. falcão, 3. leão, 4. urso, 5. leopardo, 6. galo, 7. touro, 8. unicórnio (?), 9. n.d., 10. n.d., 11. cervo, 12. javali, 13. caçador, 14. cão, 15. lebre, 16. grou, 17. pavão, 18. cisne, 19. ganso, 20. elefante.

*No f. IIr se entreveem ainda alguns restos de indicações (por ex.: pauo), mas a tinta se apagou.
1. Jano, 2. Saturno, 3. Júpiter, 4. Juno, 5. Tellus, 6. Céres, 7. Diana, 8. Vênus, 9. Minerva, 10. Fortuna, 11. Vesta, 12. Tétis, 13. Netuno, 14. Vulcano, 15. Plutão, 16. Hércules, 17. Marte (vestido como um cavaleiro medieval), 18. Mercúrio (figurado como um anjo), 19. Apolo, 20. Baco.

*No f. Iiv, estão desenhados os meda1hões completos, exceto os números 16-20, com os nomes das divindades a serem representadas (o número $8 \mathrm{com}$ um atributo: aureum poтит иепиs). Para os números 16-20, encontram-se apenas pequenas rubricas nas margens da iluminura.

\section{Primeira idade, de Adão ao dilúvio [ $1^{\circ}$ compartimento: $1^{\circ}$ registro, direita]}

Esquerda: o arcângelo Miguel, vestido como cavaleiro, pisa sobre o dragão. $1^{\circ}$ plano: Adão trabalha a terra. Direita: o sacrifício de Abel. Direita, $2^{\circ}$ plano, Set e Enos.

\footnotetext{
*michel archangelus draconem lancea occidit - $\dagger$
}

Esquerda: Lúcifer, coroado e vestido suntuosamente, com os dizeres "Ponam sedem meam ad Aquilonem. Similis ero altissimo" (Is 14, 13-14). $1^{\circ}$ plano: Lamech mata Caim. Direita: construção da cidade de Enoch.

\footnotetext{
*lucifer angelus - cayn lamech sagitta occidens puerum arcu - enoch ciuitatem edificans.
} 
Elisa BRILLI. As formas da história. A doutrina agostiniana das seis idades do mundo...

\section{Segunda idade, de Noé à confusio linguarum $\left[2^{\circ}\right.$ compartimento: $1^{\circ}$ registro, esquerda]}

$1^{\circ}$ plano: Noé bêbado e nu. $2^{\circ}$ plano: sob duas arcadas, duas personagens barbadas (Sem e Jafé?) $1^{\circ}$ plano: construção da torre de Babel (rubrica babel turris). Esquerda: Nemrod com arco e flecha, vestido como caçador. Direita, diante da torre: Semirâmide entronada dá ordens a um operário para construir um muro. ${ }^{1} 2^{\circ}$ plano: Nino e Belo em vestimentas reais

*regnum assiriorum - nebroth gigans faretram et arcum tenens - belus ninus regent - semiramis ciuitatem edificans.

\section{Terceira idade, de Abraão à deposição de Saul [ $3^{\circ}$ compartimento: $2^{\circ}$ registro, direita]}

Esquerda: sacrifício de Isaac (o anjo segura a espada de Abraão; Isaac sobre o altar, na vegetação, espreita-se a cabra que o substituirá). Direita: Isaac agora velho, nimbado e cego diante de um caminho (variações da coluna que divide os dois compartimentos de cada registro). ${ }^{2}$ Direita, $2^{\circ}$ plano: Moisés recebe as tábuas da lei.

*abraham ... fili... spada... - ysaac caligans jacobs $\dagger$
O compartimento é subdividido em quatro espaços. Nos dois superiores, em vestimentas de soberano, Enéas e Cécrope. Fundadores de Roma e de Atenas. Nos dois inferiores: figurados de modo especular e armados com arco, Ismael e Esaú.

$* \dagger$ rex-hismahel-esau irsutus - cecrops
rex.

\section{Quarta idade, de Davi ao exílio na Babilônia [4 compartimento: $2^{\circ}$ registro, esquerda]}

Esquerda: Davi e Salomão com coroa e cetro. Direita: Jéu assassina Jorão em fuga (os cavalos do carro saem da cidade de Deus através de uma das portas do córnice). ${ }^{3}$

* david et salemon $[\mathrm{sic}]$ sceptrum tenentes $-\dagger$
Esquerda: Golias vestido como cavaleiro. Dois espaços centrais superpostos: o faraó Neco e o rei de Israel, Jeroboão. ${ }^{4}$ Direita: o quarto personagem não é identificável. ${ }^{5}$

* golias loricatus scutatus hastatus gigas - jeroboam rex-pharao nechao.

1 A imagem sintetiza duas campanhas de construção diferentes, a da torre por desejo de Nemrod e a dos muros da Babilônia (que, na iluminura, circundam a torre), sob a supervisão de Semirâmide. Assim, por exemplo, conta Isid. Hisp., Chronica maior, Secunda aetas, 9 e 12, PL 83, col. 1023A ("Hanc turrim Nembrot gigas construxit...") e 1024A ("Muri quoque Babyloniae a Semiramide regina Assyriorum aedificantur").

2 A importância dada a Isaac cego e ancião (que relega a um segundo plano a consigna das tábuas da lei, cronologicamente posterior e habitualmente mais importante) remete à expulsão de Esaú, retratada no compartimento correspondente da ciuitas diaboli e subentende a cena de bênção de Jacó (omitida na imagem, mas prevista no rascunho). O caminho em que está Isaac se situa por volta da metade do corpo do Cristo: o detalhe poderia ter um significado alegórico (uma referência à chaga no torso?), para a qual eu não encontrei ainda, contudo, correspondentes textuais.

3 Cf. $2 \operatorname{Re} 9$. 
Elisa BRILLI. As formas da história. A doutrina agostiniana das seis idades do mundo...

\section{Quinta idade, do retorno da Babilônia à encarnação \\ [5 compartimento: $3^{\circ}$ registro, direita]}

Esquerda: reconstrução de Jersualém (em cima da cidade, um homem com um corno). ${ }^{6}$ Direita: Judá e Jônatas (Macabeu), vestidos como cavaleiros, com escudo e estandarte.

*zorobabel ciuitatem edificans $\dagger-j u d a s$ et jonatas loricati et scutati.
Sobre os dois lados de um edifício: Cambises e Artaxerxes com espadas. Embaixo, no aro: Antíoco e Bacchides a cavalo, vestidos como cavaleiros, com escudo e espada.

* cambises et antaxerses reges cum sceptrum tenentes manibus ${ }^{7}$ - anthiochus rex et bachides loricati.

\section{Sexta idade, da pregação de João Batista ${ }^{8}$ ao fim dos tempos [ $6^{\circ}$ compartimento: $3^{\circ}$ registro, esquerda]}

Esquerda, acima: São João Batista. Direita, acima: São Pedro com as chaves e maquete da cidade. Embaixo: Santo Estêvão com um estandarte e a palma do martírio; São Martinho de Tours com mitra e maquete da cidade; Santa Inês com lírio e rosa. ${ }^{9}$

*johannes baptista $\dagger-$ petrus clauis $\dagger-$ martir stephanus cum vexillo et palma - martinus $\dagger$-agnes cum lilis et rosa.
Em cima, aos dois lados de um edifício: Herodes com espada e Nero com cetro. Embaixo, no aro: um monge com livro e turíbulo, a quem um personagem pagão dá uma ordem (o diácono Nicolau, fundador da seita dos nicolaítas). ${ }^{10}$

*herodes rex - nero - nico $<l>$ aus diaconus tirans $\dagger$ profectus.

\section{Último registro}

Esquerda, arcada: São Paulo com um fólio branco. Arcada central: anjo escrevendo. Direita, arcada: São João com um fólio branco.

*ang $<$ elus $>{ }^{l l}$ scribens sedens - paulus stans cum breui $\dagger-$ johannes euangelista cum $\dagger$

\begin{abstract}
Esquerda: Apuleio e Platão com fólios brancos. No centro: Varrão, sentado em vestes de escriba. A arcada trilobular sob a qual se encontra o personagem está ladeada por dois grupos de construções (uma alusão a Roma, citada no rascunho?). Direita: Hermes e Virgílio com fólios em branco.

*apuleius et plato philosophi-varro sedens et scribens - ermes ${ }^{12}$ - virgilius poeta. *(sotto) regnum romanum.
\end{abstract}

4 Contra o qual, cf. Am 7, 9-11.

5 A partir de LABORDE, op. cit., todos os estudiosos desta imagem consideraram o pharao nechao do rascunho como duas personagens distintas. Deste ponto de vista (em que os dois nomes se seguem sem pontuação), bem como de um ponto de vista histórico (sobre o faraó Neco, cf. 2 Reg 23, 29 e 31-35; 2 Par. 35, 20-24 e 36, 1-4), isso não parece possível. A quarta personagem foi adicionada independentemente pelo iluminador.

6 Talvez reminiscência de Esdras 3,1.

7 Na imagem, as personagens portam duas espadas, e não cetros. 
Recebido: 20/05/2011 - Aprovado: 05/08/2011

8 Apesar da presença de João Batista, os comentadores desta imagem seguem a partição costumeira e fazem começar a sexta idade com o advento de Cristo. A escolha do conceptor da iluminura é mais precisa e lembrar-se-á que Agostinho, no comentário ao salmo 92 (datado de 412), havia retificado o que afirmara anteriormente e antecipado a passagem da quinta à sexta idade para o momento de pregação de João Batista (Enarr. In Ps. XCII 1, mas também In Iohan euang. IX 6).

9 A seleção exemplifica a articulação canônica da ciuitas dei celeste em profetas (João Batista), apóstolos (São Pedro), mártires (São Estêvão), confessores (São Martinho de Tours), virgens (Santa Agnes). A escolha desses exempla específicos, que poderia ter nexos específicos com o mosteiro de Bosau, ainda precisa ser esclarecida.

${ }^{10}$ A escolha de Nicolau e dos nicolaítas parece significativa no meio monástico de elaboração do manuscrito, no qual essa heresia, vulgarizada no pecado de concubinato, tinha uma atualidade especial. De resto, essa escolha pontua o nexo com a ciuitas dei, particularmente com Santo Estêvão, que, junto com Nicolau, foi eleito dentre os sete primeiros diáconos.

${ }^{11}$ Alguns sugeriram que a abreviação ag (com um titulus sobre o "g") do rascunho quisesse dizer aug $<$ ustinus $>$, e não ang $<$ elus $>$, de onde um erro do iluminador. Os "n"s dessa mão são bastante distintos dos "u"s, e, como já concluía Laborde, não há razão para duvidar das intenções do programa. De modo mais geral, o bispo de Hipona não é um objeto do discurso desenvolvido na dupla página, mas o enunciatário implícito e, consequentemente, mais do que opõe Agostinho aos sábios pagãos, as duas miniaturas opõem, como faz Agostinho, a verdade das Escrituras (o anjo escriba) às doutrinas filosóficas.

${ }^{12}$ LABORDE, op. cit., surpreendia-se por Hermes ser classificado como um poeta ao lado de Virgílio e sugeria que pudesse se tratar de Ênio. Depois dele, os críticos sempre propuseram a identificação de Hermes com um ponto de interrogação. No rascunho, a grafia Ermes é clara, e poeta, no singular, refere-se apenas a Virgilius. Eu lembro aqui que a doutrina hermética em matéria de idolatria e de demonologia é longamente discutida no livro VIII do De ciuitate, capítulos 23 a 26. 